ISSN : 2252-8385

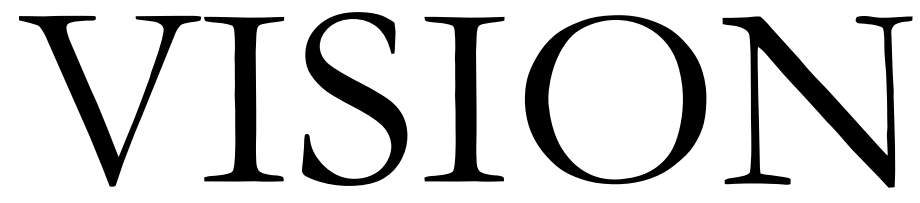

Journal for Language and Foreign Language Learning

Journal Vision, Volume 3 Number 2, October 2014

\title{
Advisor
}

Darmuin

Chief of Editor

M. NaD Annury

\section{Board of Editor}

Siti Tarwiyah Lulut

Widyaningrum Fina

Sa adah

\section{Administrative Manager}

Sayyidatul Fadlilah

Published by:

English Department

Faculty of Tarbiyah and Teacher Training Walisongo

State Institute for Islamic Studies Semarang Jl. Prof.

Dr. Hamka Km. 2 Ngaliyan Semarang

Phone: 024-7601295 Fax: 024-7615387 


\section{CONTENTS}

EPISTHEMOLOGICAL STUDY OF TERATAI METHOD: NEW OFFER ON ARABIC LANGUAGE TEACHING METHODOLOGY FOR BEGINNERINTERMEDIATE LEARNER IN INDONESIA Naifah - 5

STUDENT - TEACHER INTERACTION:

A CASE OF THE SECOND YEAR OF STATE SENIOR HIGH SCHOOLS IN CEPU Andika Cahya Ari Wibowo - 25

IMPROVING STUDENTS READING COMPREHENSION BY USING KNOW, WANT TO KNOW, AND LEARN (KWL) TECHNIQUE

Pancarini Dyah Rahayuningsih \& Eka Wulandari - 43

THE APPROPRIACY OF ASSESSMENT

IN THE JUNIOR HIGH SCHOOL ENGLISH TEXT BOOKBASED ON THE 2013 CURRICULUM

Siti Tarwiyah - 55 
PROMOTING FUN LEARNING IN GRAMMAR CLASS THROUGH SONGS

Nuraeningsih - 69

\begin{abstract}
CTL MODEL TO ACTIVATE STUDENTS PARTICIPATION IN SPEAKING CLASS AT ENGLISH EDUCATION PROGRAM
\end{abstract}

Semi Sukarni - 79

UTILIZING LEARNING PLATFORM FOR PAPERLESS CLASSROOM

Wenty Dwi Yuniarti - 105

الترادف في اللغة العربية

MuDdah - 125

THE ANALYSIS OF M.A.K HALLIDAY S THEORY OF SYSTEMIC FUNCTIONAL LINGUISTIC AND ITS IMPACT TO DISCOURSE ANALYSIS AND GENRE-BASED APPROACH Mohammad Andi Hakim - 139 



\title{
STUDENT - TEACHER INTERACTION:
}

\section{A CASE OF THE SECOND YEAR OF STATE SENIOR HIGH SCHOOLS IN CEPU}

\author{
Andika Cahya Ari Wibowo \\ SMP N 1 Blora
}

\begin{abstract}
The purposes of the study are to Dnd out the amount of language produced by the teacher (Teacher Talking Time) and by the students (Student Talking Time) and to identify the characteristics of the classroom interaction in the Senior High School English classes. The study involved the second year students and the English teachers of SMA N I Cepu and SMA N II Cepu as the object of the study. Observation method is utilized in the study to collect the data. The study is supported by one thousand four hundreds and forty data which are categorized into the ten categories of Flanders (FIAC).

In details, the Drst result of the analysis shows that $70.5 \%$ of the classroom available time was taken by the teacher and the students only took $21.6 \%$ of the available time during the interaction in SMA N I Cepu. Meanwhile, during the interaction in SMA N II Cepu the teacher took $69.6 \%$ of the classroom available time while the students only took $22.2 \%$ of the available time.

The second result shows that the dominant characteristic of the classroom interaction in SMA N I Cepu was Teacher Talking Time while the dominant characteristic in SMA N II Cepu was Con- tent Cross.
\end{abstract}

Keywords : Classroom Interaction, Flanders Interaction Analyze Categories (FIAC), Teacher Talking Time, Student Talking Time, The Characteristics of Classroom Interaction 


\section{Introduction}

The interaction between the students and the teacher in the classroom is an important factor that inDuences the learning outcomes. Ylane, in her study, in http://www.ingentaconnect.com/ content/klu/leri/2003/00000006/00000001/05119454?crawlertru states that study success is determined by the interaction between the students and their teacher. Everyone may learn something better if he/she experiences it by himself/herself (through interaction). When the students get involved in the classroom activities, they will master the subject better. The students who are active in conversation through taking turns may develop their language. Meanwhile, the students who are passive in conversation have less opportunity to learn. Additionally, it is argued that success or failure in classroom language learning typically has something, if not absolutely everything, to do with the nature of the interaction that takes place during lessons (http : // www.ling.lancs.ac.uk).

Teachers failure in maintaining classroom interaction will directly result to an unfulDlled of objective of teaching. Speaking to this point, Nunan (1992:37) points out that if a teacher fails in classroom interaction, it may cause misunderstanding between him and the learners. So, the teachers cannot achieve the objectives.

However, it should be remembered that it is not necessary for the teachers to dominate the classroom interaction but it is necessarily recommended to have a good interaction with the students. Taking into consideration of the signiDcant role of classroom interaction in teaching and learning process, I assume that it is important to explore the students - teacher interaction in the classroom.

To specify the matter, this study will focus on the students teacher interaction in the senior high school. The reason is because senior high school is a formal place in which youngsters (students) are being prepared to live in a multi - racial society where the communication and interaction skill are urgently needed.

In this study I also give special attention to the "state senior high school, because according to me state senior high school should become a pioneer and an example of successful English Teaching and Learning for other senior high schools (private high schools). 
Student - Teacher Interaction ...

The Role of Classroom Interaction in the Learner Language

\section{Development}

We may not claim to know enough about what it is about language classroom that enables learners to develop their second or foreign language acquisition. However, as Interaction Hypothesis (johnson \& johnson, 1998/99:174) states that the position that what promotes the development of second (or foreign) language proDciency is the process of face-to-face linguistic interaction, it makes sense for us to want to try to understand the contribution of classroom interaction to the learners language development.

During the process of interaction, there is greater opportunity for the learners to learn new language forms from their interlocutor. They have opportunities to clarify a language form that they perceive as a new form for them since that their interlocutor is a live conversation source which can explain or clarify what he/she has said to them in which in this case he/she may give additional information that makes them understand or comprehend the conversation; and this comprehension which facilitates their acquisition of the second language. It is quite different when they learn the new language forms from input itself which perhaps through participating in drill activities or listening to conversational cassettes. It is due to the fact that they cannot clarify the forms that they do not understand during their involvement in those activities since that those activities only provide them with a dead conversation source.

In addition, Allwright and Bailey (1994:121) point out that it is the effort made by the learner to comprehend the input that fosters development where this effort is made in face-to-face interaction. They refute Krashen s Input Hypothesis that modiDed and comprehensible inputs are best for language acquisition. Further, they state that language acquisition can perhaps best be seen, not only as the outcome of an encounter with comprehensible input, but as the direct outcome of the work involved in the negotiation process itself.

There is also another way in which interaction may assist learners. As Ellis (2003:47) has commented that when learners have the chance to clarify something that has been said, they are giving themselves more time to process the input which may help them not just 
to comprehend but also to acquire new L2 forms.

\section{Teacher Talk}

It is commonly established that teacher talk plays a signiDcant role to language teaching. It refers to the special language that the teacher uses when interacting with the students in the classroom. According to Thuraisingam in http://www.aare.edu.au/Olpap/ thuO1057.htm, it is usually restricted to the teacher presenting in- formation, giving direction, asking questions, accepting or rejecting ideas and students initiating responds or questions.

Regarding to the deDnition above, it is somehow obvious that teacher talk dominates the classroom interaction. It is perhaps that talk in classroom is structured differently from other kinds of talk because of the very nature of instruction. Pica as quoted by Goh and Silver (2004:225) has laid out several reasons for this. One is expectations about teacher and learner roles. We expect teachers to ask questions and students to answer. If students ask too many questions, teachers might feel that their authority is being challenged. Also, teachers often make every attempt to ensure comprehensibility for the students, thus avoiding the need for negotiation for meaning.

This phenomenon certainly brings a bad implication to the students since that there may be relatively few opportunities for them to negotiate meaning which later may be resulted in the student $\mathrm{s}$ failure of acquiring the target language. Hence, teacher has to be aware of this phenomenon and consider his talk to be in balance with the students talk and classroom atmosphere for the sake of promoting maximum learning to the students.

During the teaching and learning process, teacher talk provides a considerable input to the students learning. Even though it has already been proven that input in itself may be insufDcient to bring about maximum language learning to the students, it is still urgently needed by the students. As O neil in http://www.btinternet. $\mathrm{com} /+$ ted.power/esl0420.html speaks to this point as follows:

"there is a lot of evidence that strongly suggests that all learners need 'input and that 'negotiated input is always essential. Nego- 
tiated input means the kind of conversation, talk or formal teaching in which the teacher and the students together negotiate both what they are talking about and the language used to talk about it.

In conveying the input, teacher needs to make an adjustment and modiDcation to his/her speech in order to make it comprehensible to the students. It is due to the fact that not all the target language is understandable for the students, only some of the language they hear makes sense to them. Therefore, in making adjustment and modiDcation teacher needs to be familiar and sensitive to the students need for comprehension and the pedagogical purposes.

In addition, Chaudron (1993:85) suggests some Dndings which characterize the teachers adjustment and modiDcation in conveying the comprehensible input as follows:

1. Rate of speech appears to be slower.

2. Pauses, which may be evidence of the speaker planning more, are possibly more frequent and longer.

3. Pronunciation tends to be exaggerated and simpliDed.

4. Vocabulary use is more basic.

5. Degree of subordination is lower.

6. More declaratives and statements are used than questions.

7. Teachers may self - repeat more frequently.

\section{Systems of Interaction Analysis}

There are numerous systems of interaction analysis have been proposed by many experts. One is Fanselows (1977a) system for either live observation or analysis from a recording. He made major modiDcations to Bellack s pioneering analytical system to produce 'FOCUS (Foci for Observing Communications Used in Settings). Fanselow s system, in fact, does not have separate categories for teachers and students, but instead has general categories that can be used regardless of who the participants are or what role they play in the interaction. Second is 'FLint (Foreign Language Interac- tion) produced by Moskowitz (1968, 1970, 1971, 1976). This FLint system was derived from Bales s (1950) work on group processes and Flanders s (1960/1970) adaptation of this for classrooms. Her adaptation for L2 classrooms involved the separate simultaneous 
real - time coding for language of each behavior (1970) and later, categories for drill and feedback behaviors (1976).

Another system which will underlie this study is that developed by Flanders since that this system is quite simple and practical than others. Flanders analysis aimed to help teachers develop and control their teaching behavior and to investigate the relationship between teaching behavior, classroom interaction and educational outcomes. He devised a ten - category system of interaction analysis (FIAC) and classiDed all talk that occurs in the classroom into'. Teacher Talk and 'Student Talk. Further, his ten - category system is able to record teachers direct and indirect inDuence on the stu- dents during classroom interaction.

Flanders as quoted by Wragg (1994:34-35) divides his ten categories as follows:

1. Accepts feeling: accepts and clariDes the feeling tone of the students in a non - threatening manner. Feelings may be positive or negative. Predicting and recalling feelings are included.

2. Praises or encourages: praises or encourages student action or behavior, jokes that release tension, not at the expense of another individual, nodding head or saying "uh uh? or "go on are included.

3. Accepts or uses ideas of student: clarifying, building or developing ideas or suggestions by a student. As teacher brings more of his own ideas into play, shift to category Dve.

4. Asks question: asking a question about content or procedure with the intent that a student answer.

5. Lectures: giving facts or opinions about content or procedure; expressing his own idea; asking rhetorical questions.

6. Gives directions: directions, commands or orders with which a student is expected to comply.

7. Criticizes or justiDes authority: statements, intended to change student behavior from non - acceptable to acceptable pattern, bawling someone out; stating why the teacher is doing what he is doing, extreme self - reference.

8. Student talk - response: talk by students in response to teacher. Teacher initiates the contact or solicits student statement. 
9. Student talk - initiation: talk by students, which they initiate. If "calling on students is only to indicate who may talk next, observer must decide whether student wanted to talk. If he did, use this category.

10. Silence or confusion: pauses, short periods of silence and periods of confusion in which communication cannot be understood by the observer.

\section{Purpose of the Study}

This study is intended to Drst, Dnd out the amount of language produced by the teacher (Teacher-Talking Time) and by the students (Student-Talking Time). Secondly, it is to identify the different characteristics of the classroom interaction in the state senior high school English classes.

\section{Research Design}

As stated in the previous chapter, the study is conducted in mainstream classroom setting and focused on the interaction maintained by the students and the teacher. There are two considerations taken into account in determining the design of the study. Firstly, the data that are expected from this study are in the form of numbers. Secondly, the study is conducted to answer the problems, to identify and later to present the characteristics of classroom interaction which are in the form of rank order. Due to the objectives of the study, most of the analyses are consequently done with numbers, too. Those two considerations may be somewhat sufDcient to classify the study into quantitative research design. As Hall (2002: 133) points out that quantitative data are usually expressed in terms of numbers and amounts while qualitative data are not.

In line with Hall $\mathrm{s}$ opinion, Cormack in http://www.fortunec- ity.com/ GreenDeld/ Grizzly $/ 432 / \mathrm{rra} 2 \mathrm{htm}$ deDnes quantitative research as a formal, objective, systematic process in which numeri- cal data are utilized to obtain information about the world.

\section{Object of the Study}

The objects of the study are two classes. They are the second 
year students of SMA Negeri I Cepu which is located on Jln. Dipo- negoro no $55 \mathrm{Cepu}$ and the second year students of SMA Negeri2 Cepu which is located on Jln. Randu Blatung km. 5. Both of the schools are located in Kabupaten Blora; Central Java. Thus, the main objects in this study are the students and their English teachers.

The observation will be held in English classes where the classroom interaction takes place. It will be done during the teaching and learning process in different times. Thus, the data is documented in the form of recorded verbal behaviors which are the students and the teachers utterances that taken place in the interaction between the students and the teacher during the teaching and learning process in the classroom.

\section{Instrument of the Study}

The instrument utilized in this study is FIAC (Flanders In- teraction Analyze Categories). It is a standardized check list type instrument which has the following steps as the procedures:

Step 1: Filling in the Data Recording Sheet

The observer records across the record sheet every Dve seconds so that each line represents one minute of classroom time.

Step 2: Getting the Back up Data by Coding the Verbal Interaction

In order to get the backup data, the observer translates the data which have been recorded by a tape recorder into a descriptive code. Each verbal behavior is recorded as a number which represents the ten categories of Flanders. Here is the example:

\section{Illustration of Verbal Interaction}

\begin{tabular}{|l|l|}
\hline Actual classroom verbal interaction & Recorded as \\
\hline Teacher: Look at the list of cities on & 6 (command) \\
the board. & 4 (question) \\
Which do you think is the one nearest & 10 (silence) \\
here? (pause) & 8 (solicited pupil talk) \\
$\begin{array}{l}\text { Student: It s either Bristol or Birming- } \\
\text { ham }\end{array}$ & \\
\hline
\end{tabular}


Student - Teacher Interaction ...

Step 3: Plotting the Coded Data into a Matrix

To plot the coded data into a matrix, we need to put them in pairs as illustrated follows:

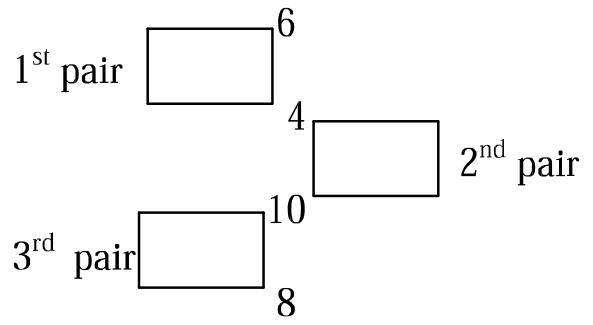

Each pair of the coded data is tallied in one of the matrix s cells. The matrix consists of ten columns and ten rows. Thus, it gives a 100 little squares or 'cells . Each column and row represents one of the ten categories of the Flanders coding system. Below is the sample matrix:

\section{Sample matrix for recording interaction analysis} Second Event

\begin{tabular}{|c|c|c|c|c|c|c|c|c|c|c|c|c|}
\hline \multirow{12}{*}{$\begin{array}{l}\text { First } \\
\text { Event }\end{array}$} & & 1 & 2 & 3 & 4 & 5 & 6 & 7 & 8 & 9 & 10 & total \\
\hline & 1 & & & & & & & & & & & \\
\hline & 2 & & & & & & & & & & & \\
\hline & 3 & & & & & & & & & & & \\
\hline & 4 & & & & & & & & & & & \\
\hline & 5 & & & & & & & & & & & \\
\hline & 6 & & & & & & & & & & & \\
\hline & 7 & & & & & & & & & & & \\
\hline & 8 & & & & & & & & & & & \\
\hline & 9 & & & & & & & & & & & \\
\hline & 10 & & & & & & & & & & & \\
\hline & total & & & & & & & & & & & \\
\hline
\end{tabular}


Step 4: Analyzing the Teacher Talking Time (TT'T) and the Student Talking Time (ST'T)

To analyze the time which is taken up by the teacher and by the students, I set up two equations. Firstly, I set up an equation by putting the tallies of the categories 1-7 in the numerator and the total tallies of the categories 1-1fl in the denominator to determine T'TT.

Then I set up the second equation by putting the tallies of the categories 8-9 in the numerator and the total tallies of the categories 1-1fl in the denominator to determine the STT. Below are the equations:

$$
\begin{aligned}
& \mathrm{TTT}=\frac{\text { categories } 1-7}{\text { categories } 1-\mathbb{0}} \xi 100 \% \\
& \mathrm{TTT}=\frac{\text { categories } 8-9}{\text { categories } 1-\mathbb{0}} \xi 100 \%
\end{aligned}
$$

Step 5: Analyzing the Matrix

In plotting the coded data into a matrix, some areas have tallies than others. A heavy concentration of tallies in a certain area gives information about who is talking and what kind of talk is taking place. The following is the example of the above explanation.

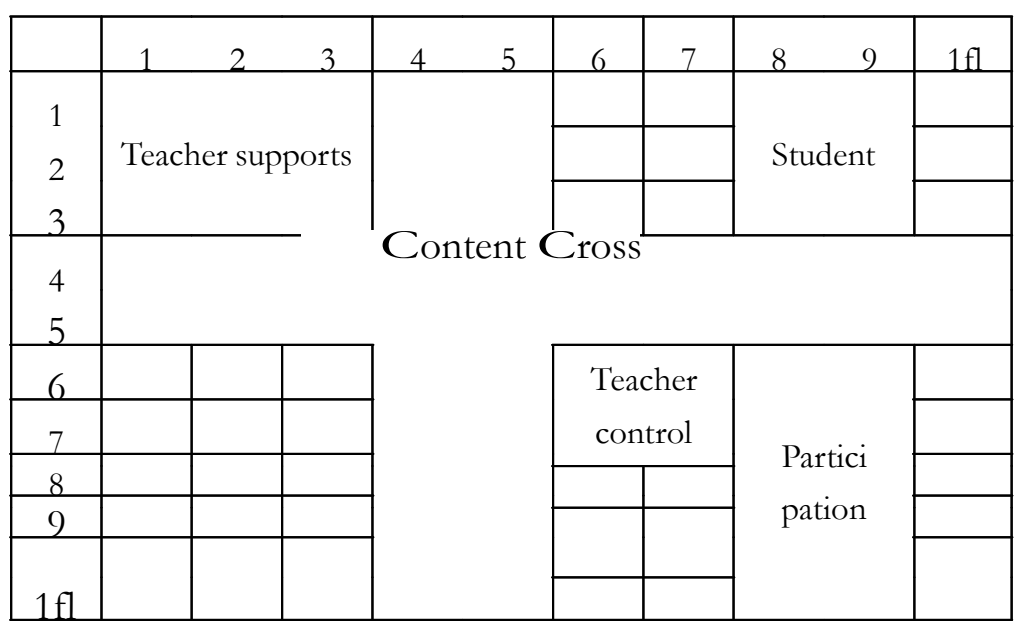


This matrix analysis presents the types of interaction characteristics as follows:

1. Content Cross

A heavy concentration in columns and rows 4 and 5 indicates teacher dependence on questions and lectures

2. Teacher Control

A concentration in columns and tows 6 and 7 indicates commands and reprimands by the teacher

3. Teacher Support

A concentration in columns and rows 1, 2, and 3 indicates that the teacher is reinforcing and encouraging the students to participate more in the classroom interaction

4. Student Participation

A concentration in columns and rows 8 and 9 indicates the student responses to the teacher

Step 6: Analyzing the Additional Data

Adding the tallies in one column and comparing that to the tallies in other columns can determine the percentage of time spent on that activity. The following technique will provide a way of Dnding out how direct or indirect a teacher is. It is determined by setting up an equation. The equation results in the indirect teacher ratio as follows:

$$
\text { Indirect Ratio }=\frac{\text { Indirect Teacher Influence }(\text { categories } 1-4)}{\text { Total Teacher Influence }(\text { Categories } 1-7)}
$$

The closer the result gets to 0.0 , the more direct the teacher is. On the other hand, the closer it gets to 1.0 the more indirect the teacher is.

\section{Procedures of Data Collection}

The data collection activity is conducted through several steps. Firstly, I ask the school headmaster s permission to collect the data by doing observation in the classroom. It is necessary since that everybody needs to know about what is going to happen in order to 
build the willing and cooperative relationship. As soon as I get the permission, I see the English teachers to make an appointment for doing the observation.

Each classroom interaction is recorded in two class periods. The time of collecting the data follows the teacher schedule. To begin the process, I come to the class early before the teaching and learning activity is started in order to prepare the equipment. Then, I sit in the strategic position in which I am able to observe the natural interaction between the teacher and the students clearly. As soon as the teacher starts the teaching, I start to Dll in the data recording sheet with 12 squares available for each minute of time. Every Dve seconds the category number is recorded which best describes what is taking place. During this process, I also use a stop watch (timer) to remind me to record a category every Dve seconds. This process is lasted in thirty minutes. Further, in order to get a back-up data, I also use a tape recorder to record the verbal behaviors that taken place during the classroom interaction.

\section{Procedures of Data Analysis}

The data analysis of the classroom interaction is descriptive in nature. The six steps of FIAC are presented following the detail given before:

Step 1: Dlling in the data recording sheet

Step 2: getting the backup data by coding the verbal interaction

Step 3: plotting the coded data into a matrix

Step 4: analyzing the teacher talking time (TTT) and the student talking time (ST'T)

a. $\mathrm{TTT}=\frac{\text { categories } 1-7}{\text { categories } 1-10} \times 100 \%$

b. STT $=\frac{\text { categories } 8-9}{\text { categories } 1-10} \times 100 \%$

c. Periods of silence $=\frac{\text { Categories } 10}{\text { Categories } 1-10} \times 100 \%$ 
Step 5: analyzing the matrix to the categories below:
a. content cross
: columns and rows 4 and 5
b. teacher control
: columns and rows 6 and 7
c. teacher support
: columns and rows 1-3
d. student participation
: columns and rows 8 and 9

Step 6: analyzing the additional data

$$
\text { Indirect ratic }=\frac{\text { categories } 1-4}{\text { categories } 1-7}
$$

The completed matrix gives description about the characteristics of classroom interaction of second year classes of SMU N 1 Cepu and SMU N 2 Cepu. After the matrix is completed, the eight characteristics (Teacher Talking Time, Student Talking Time, Peri- ods of Silence, Content Cross, Teacher Control, Teacher Support, Student Participation and Indirect Ratio) of classroom interaction are identiDed. The identiDcation result is then converted into per- centages in order to be put into a rank ordering of the most domi- nant to the least dominant.

\section{Research Finding}

The characteristic of the classroom interaction of those two senior high schools is put in an order as summed up in these following two tables.

\begin{tabular}{|c|c|c|}
\hline No & Characteristics & Proportion (\%) \\
\hline 1 & Teacher Talking Time & 70.5 \\
\hline 2 & Content Cross & 54.8 \\
\hline 3 & Indirect Ratio & 53.2 \\
\hline 4 & Student Participation & 52.6 \\
\hline 5 & Student Talking Time & 21.6 \\
\hline 6 & Periods of Silence & 7.7 \\
\hline 7 & Teacher Control & 3.1 \\
\hline 8 & Teacher Support & 0.5 \\
\hline
\end{tabular}

The Rank Order of the Characteristics of the Classroom Interaction of the Second Year Student of SMA N I Cepu 


\begin{tabular}{|c|c|c|}
\hline No & Characteristics & Proportion (\%) \\
\hline 1 & Content Cross & 81.3 \\
\hline 2 & Teacher Talking Time & 69.6 \\
\hline 3 & Student Participation & 40.8 \\
\hline 4 & Indirect Ratio & 37.4 \\
\hline 5 & Student Talking Time & 22.2 \\
\hline 6 & Periods of Silence & 8 \\
\hline 7 & Teacher Control & 3.8 \\
\hline 8 & Teacher Support & 0.4 \\
\hline
\end{tabular}

The Rank Order of the Characteristics of the

\section{Classroom}

Interaction of the Second Year Student of SMA N II Cepu

The Drst table illustrates that the teacher talking time $(70.5 \%)$ is the most dominant characteristic of the classroom interaction. It means that the teacher takes most of the available time than the students during the interaction.

The second dominant characteristic is the content cross (54.8). The content cross proDle here is stated to be more indirect, because the number of tallies in category 4 is bigger than that in the category 5 .

Indirect ratio $(53.2 \%)$ is the third dominant characteristic of the classroom interaction. Based on the indirect ratio, it has the indirect ratio of 0.532 . It indicates that the teacher has indirect inDuence since that the ratio (0.532) is closer to 1.0.

Student participation $(52.6 \%)$ is the fourth characteristic of the classroom interaction. Form the Dnding, it can be interpreted that the students are active in teaching-learning process.

The Dfth characteristic is the students talking time (21.6\%), which shows that the students have less change to participate in the classroom interaction verbally than the teacher.

The sixth characteristic is the periods of silence $(7.7 \%)$ which shows that the available time has been used effectively either by the teacher or the students that is indicated by the low percentage of this proDle.

The teacher control (3.1) is the seventh characteristic of the classroom interaction. It indicates that the teacher spends a little 
time for giving directions and criticizing or justifying activity.

The last characteristic is the teacher support $(0.5 \%)$. It indicates that the teacher uses relatively little time to accept feeling and to praise or encourage the students as well as to accept or use the students ideas. Based on the interpretation above, it can be concluded that the teacher talking time is the most dominant characteristic of the classroom interaction of SMA N I Cepu.

The second table illustrates that the content cross $(81.3 \%)$ is the most dominant characteristic in the classroom interaction. The content cross proDle here is stated to be more direct since the number of tallies in category 5 is bigger than that in the category 4 .

The second dominant characteristic is the teacher talking time (69.6\%). It shows that most of the time available is taken up by the teacher which indicates that the teaching-learning process is teacher centered. Student s participation $(40.8 \%)$ is the third dominant characteristic of the classroom interaction. It indicates that the student participation is a signiDcant characteristic of the classroom interaction. The fourth characteristic is the indirect ratio (37.4\%). Based on the indirect ratio, it has the indirect ratio of 0.374 . It indicates that the teacher has direct inDuence since that the ratio (0.374) is closer to 0.0 .

The Dfth characteristic is the student talking time $(22.2 \%)$ that shows that the students have less verbal participation in the classroom interaction than the teacher. Period of silence $(8 \%)$ is the sixth characteristic of the classroom interaction. It shows that available time has been used effectively either by the teacher or the students which is indicated by the low percentage of this proDle. The seventh characteristic is the teacher control (3.8\%). It indicates that the teacher spends a small number of times during the classroom interaction to give directions and to criticize to justify the activity in the classroom.

The last characteristic is the teacher support $(0.4 \%)$. It shows that the teacher uses the relatively small number of time during the classroom interaction to accept feeling and to praise or encourage the students as well as to accept or use the students ideas.

Based on the interpretation above it can be concluded that the 
classroom interaction of SMA N II Cepu is dominated by the con- tent cross which focuses on teacher s questions and student respond in answering the teacher question and teacher s lectures.

\section{Conclusion}

Based on the tables above, it can be inferred that there are different order of the characteristics of the classroom interaction that dominated the teaching and learning process in the two different state senior high schools above. Further, it can be inferred that generally the dominant characteristics are Teacher Talking Time and Content Cross that are the teacher spends much time to give facts or opinions about content or procedure and to ask questions in which the students are expected to respond. Additionally, both of Senior High Schools have the same least characteristic of the classroom interaction that is Teacher Support. It shows that teacher spends little time to accept the students feelings and ideas and to praise or encourage the students.

\section{Suggestion}

Based on the conclusions above, I would like to offer the following suggestions:

1. Teacher should balance the amount of time spent on students talks since the students need more opportunity to speak or to initiate the talk in order to be able to speak or communicate in English Duently.

2. Teacher should increase the Teacher Support including the acceptance or the use of students feelings and ideas as well as praises and encouragements in order to motivate the students to master the English as it needs an extra work and motivation to master a foreign language. In addition, it may also keep the students away from being trapped in their frustration when they cannot easily express their ideas in English.

3. The schools should provide various English teaching media which may increase the students participation and ease the teacher in maximizing the classroom interaction which lead to the maximum student English learning. 


\section{REFERENCES}

Allwright, Dick and Kathleen M. Bailey.1994. Focus on the Language Classroom. Cambridge: Cambridge University Press.

Chaudron, Craig.1993.Second Language Classroom - Research on Teaching and Learning.Cambridge: Cambridge University Press.

Cormack. Ways of Approaching Research: Quantitative Designs. http:// www.fortunecity.com/greenDeld/grizzly/432/rra2.htm.

Ellis, Rod. 2003. Second Language Acquisition. New York: Oxford University Press.

Goh, Christine C.M and Rita Elaine Silver. 2004. Language Acquisition and Development. Singapore: Longman.

Hall, Joan Kelly. 2002. Teaching and Researching Language and Culture. Edinburgh Gate Harlow - England: Pearson Education Limited.

Johnson, Keith and H. Johnson. 1998/1999. Encyclopedic dict of Applied Linguistic. UK: Blackwell Publishers Ltd 108 Oxford.

Nunan, David. 1992. Research Methods in Language Learning. Cam- bridge: Cambridge University Press.

O Neill, Robert. Teacher - Talk in the Laguage Class. http: //www. btinternet. com/+ted.power/esl0420.html.

Thuraisingam, Pamela. Language Use and Interaction in the History Classroom. http:// www.aare.edu.au/01pap/thu01057.htm. 
Wragg, E.c. 1994. An Introduction to Classroom Observation. London and New York: Routledge.

Ylane, Lindblom. What Makes a Student Group Success]ul? Student-Student and Student - Teacher Interaction in a Problem - Based Learning Environment. http://www.ingentaconnect.com/content/klu/ leri/2003/00000006/00000001/05119454?crawler-tru. 